\title{
GENERAL NOTES
}

\section{FIRST BRITISH ACADEMIC CONFERENCE IN OTOLARYNGOLOGY, Ig63}

To be held at the Royal College of Surgeons of England, London, W.C.2, from June I 7 th to 2 Ist inclusive. (Registration from 4 p.m. on Sunday, June I6th.)

His Royal Highness Prince Philip, Duke of Edinburgh, has graciously consented to be Patron of the Conference.

The main subjects for discussion at formal sessions will be:

I. Vertigo

Speakers: Lord Brain (G.B.)

Dr. Charles Hallpike (G.B.)

Dr. John Lindsay (U.S.A.)

Dr. W. H. Johnson (Canada)

2. Stapes Surgery

Speakers: Dr. John Shea (U.S.A.)

Dr. Harold Schuknecht (U.S.A.)

Mr. G. C. Halliday (Australia)

Dr. J. Sullivan (Canada)

Mr. P. Beales (G.B.)

3. Chemotherapeutic Treatment of Cancer of Head and Neck

Speakers: Professor F. Bergel (G.B.)

Mr. P. Clifford (Kenya)

Drs. R. D. Sullivan and Elton Watkins (U.S.A.)

Mr. D. F. N. Harrison (G.B.)

4. Deafness in Children

Speakers: Professor Sir Alexander Ewing (G.B.)

Mr. Gavin Livingstone (G.B.)

Miss Edith Whetnall (G.B.)

5. Carcinoma of the Larynx

Speakers: Professor Sir Brian Windeyer (G.B.)

Dr. E. C. Easson (G.B.)

Mr. Robert Owen (G.B.)

Mr. Philip Reading (G.B.)

In each case the discussion will be initiated by invited persons.

Informal instructional sessions and film shows, also scientific and trade exhibitions, will be arranged.

A Reception will be given by the President and Council of the Royal College of Surgeons on the evening of Tuesday, June 18 th.

A Banquet will be held on the evening of Thursday, June 20 th.

Enrolment forms and further particulars may be obtained from the Hon. General Secretary, Mr. Ronald Macbeth, Department of Otolaryngology, Radcliffe Infirmary, Oxford. 


\section{General Notes}

\section{SIXTIETH FRENCH CONGRESS OF OTOLARYNGOLOGY}

Sixtieth French Congress of Otolaryngology Meeting, October 7 th to Ioth, I963. President: Mr. Ombredanne, M.D., 4 rue Logelbach, Paris. General Secretary: Mr. H. Guillon, M.D., 6 avenue Mac-Mahon, Paris.

\section{INTERNATIONAL CONGRESS OF THE HUNGARIAN SOCIETY OF OTO-RHINO-LARYNGOLOGY}

This Congress will be held in Budapest from September Igth to September 2Ist, I963.

The main subjects to be discussed will be: Tumours of the Paranasal Sinuses; Occupational Ear Disease.

Will those who intend to participate write for further information to: Dr. George Revesz, General Secretary of the Hungarian Society of Otolaryngology, Budapest, I I. Keleti Karoly u. I5/a.

\section{NORMAN GAMBLE FUND}

An amount of $£ 120$ is available from the Norman Gamble Fund of the Royal Society of Medicine for grant(s) in aid of research in otology.

Applications should be sent to the Secretary, Royal Society of Medicine, I Wimpole Street, W.I. not later than October I, I963, giving particulars of the research it is intended to carry out.

\section{UNIVERSITY OF EDINBURGH FACULTY OF MEDICINE \\ The Llewellyn Bevan Prize}

This Prize, of the value of about $f 80$, will be open for award in 1963 to a Graduate in Medicine of the University of Edinburgh for the best and approved Essay on the Pathology and Treatment of Ménière's or other Disease of the Internal Ear.

Essays in competition for the Prize must be submitted not later than October 3Ist, I963, to J. H. F. Brotherston, Dean of the Faculty of Medicine, University Medical School, Teviot Place, Edinburgh, 8.

\section{TWO COURSES IN RHINOLOGY TO BE PRESENTED AT LEIDEN UNIVERSITY, HOLLAND, IN JULY, I963}

Two courses in rhinology to be presented at the Leiden University, Holland, in July, I963, are expected to draw participants from many countries of the world.

A "Boerhaave" course in rhinology will be held July 4th-6th, I963, and will be followed by the fifth International Course in "Reconstructive Surgery of the Nasal Septum and External Pyramid", July 7th-Igth, with the cooperation of the American Rhinologic Society.

Both will be held at the Academisch Ziekenhuis, Afd. Keel-neus-oorheelkunde 


\section{General Notes}

under the direction of Prof. Dr. H. A. E. van Dishoeck of the University. Dr. Maurice H. Cottle, Professor of Otorhinolaryngology at the Chicago Medical School, will be the guest professor for the two-week course in nasal surgery. Many distinguished specialists from the United States, Europe, and other countries will join in the teaching programme.

For further information, write to Prof. Dr. H. A. E. van Dishoeck, Afd. Keel-neus-oorheelkunde, Academisch Ziekenhuis, Leiden, Holland, or to the American Rhinologic Society, 530 Hawthorne Place, Chicago I3, Illinois, U.S.A.

\section{INTERNATIONAL CONGRESS OF AUDIOLOGY}

The Seventh International Congress of Audiology will take place in Copenhagen, August 26th-29th, Ig64.

The main topics of the Congress will be: (I) Binaural hearing; (2) The acoustic impedance of the ear; (3) Modifications of speech audiometry.

\section{CALIBRATION OF AUDIOMETERS}

An announcement under this heading has appeared in the past eight numbers of this Journal. This contained an inaccurate statement to the effect that there was no existing audiometer calibration service in England and Wales before the formation of this new service by the Royal National Institute for the Deaf.

The Editor very much regrets publishing this inaccurate statement. Messrs. Amplivox have, in fact, been running an audiometer calibration service for the past fifteen years. We offer our sincere apologies to Messrs. Amplivox for overlooking their valuable and well known service.

\section{UNIVERSITY OF CALIFORNIA MEDICAL CENTER School of Medicine-Department of Surgery}

The William and Harriet Gould Foundation announces the recipient of the I962 Gould Award: Professor G. Paul Moore, Chairman of the Speech Department at the University of Florida, for his contribution to the art and science of voice pathology.

The Gould Award is presented annually for outstanding fundamental contributions in the field of laryngology. The recipient is selected by an international committee which at present consists of Professor Dr. Luzius Ruedi, Zurich, Switzerland; Professeur George Portmann, Bordeaux, Gironde, France; Dr. A. Bustamante Gurria, Medellia 94-3 Mexico, D.F., and Dr. Hans von Leden, University of California, Medical Center, Los Angeles 24, California, Chairman.

The award consists of an illuminated plaque and cash prize of $\$ 350.00$. Nominations for the I 963 award should be filed with one of the members of the international committee prior to June Ist, I963.

$$
\text { HANS VON LEDEN, M.D. }
$$




\section{General Notes}

\section{INTERNATIONAL COURSE IN NASAL SURGERY TO BE PRESENTED AT UNIVERSITY OF LEIDEN}

Forty-five specialists in rhinology from the United States, Mexico, Scotland, Australia, Israel, France and The Netherlands will constitute the invited faculty for the 5 th International Postgraduate Course in Reconstructive Surgery of the Nasal Septum and External Pyramid, to be presented at the University of Leiden, The Netherlands, July I 4 th to 27 th, 1963.

The course, directed by Prof. H. A. E. van Dishoeck of the University, will be presented with the co-operation of the American Rhinologic Society. Dr. Maurice H. Cottle, Professor of otorhinolaryngology at the Chicago Medical School, will be the guest professor.

Among the distinguished guests will be Sir Victor Negus of London, consulting Surgeon to the Ear, Nose and Throat Department of King's College Hospital, and Prof. Dr. C. A. Hamburger of the Karolinska Institute, Stockholm. Specialists from all parts of the world, will be enrolled as student participants.

The course will include lectures, surgical demonstrations, laboratory exercises and workshop exhibits. The rôle of allergy in nasal surgery will receive special attention. English will be the official language. Class membership is limited.

For further information write to: (I) Prof. Dr. H. A. E. von Dishoeck, University of Leiden, Academisch Ziekenhuis, Leiden, The Netherlands, or (2) American Rhinologic Society, 530 Hawthorne Place, Chicago r3, Illinois, U.S.A.

\section{UNIVERSITY OF BORDEAUX \\ Ear, Nose and Throat Department \\ Director Professor: Georges Portmann}

Functional Otological Micro-Surgery Post-Graduate Course will be held from July Ist to July Ioth, I963, conducted by Michel Portmann, M.D. (Associate Professor).

This is a practical course of surgical techniques given in English and is strictly reserved for medical doctors certified E.N.T. Specialists.

During this period, every assistant attending the course will be able to watch surgical interventions in the theatre, to follow theoretical courses illustrated with films regarding the major techniques, and to work on his own daily anatomical specimen with all the requisite material, including the binocular microscope.

The number of assistants is limited to 24 divided into two groups (Group I and Group 2).

Fees: 200 dollars or I,000 francs (to be paid at the Faculty of Medicine in Bordeaux) at the beginning of the course.

Applications should be sent to Docteur Michel Portmann, 45 cours Maréchal Foch, Bordeaux, France 



\section{FINE'S MOUTH GAG FRAME}

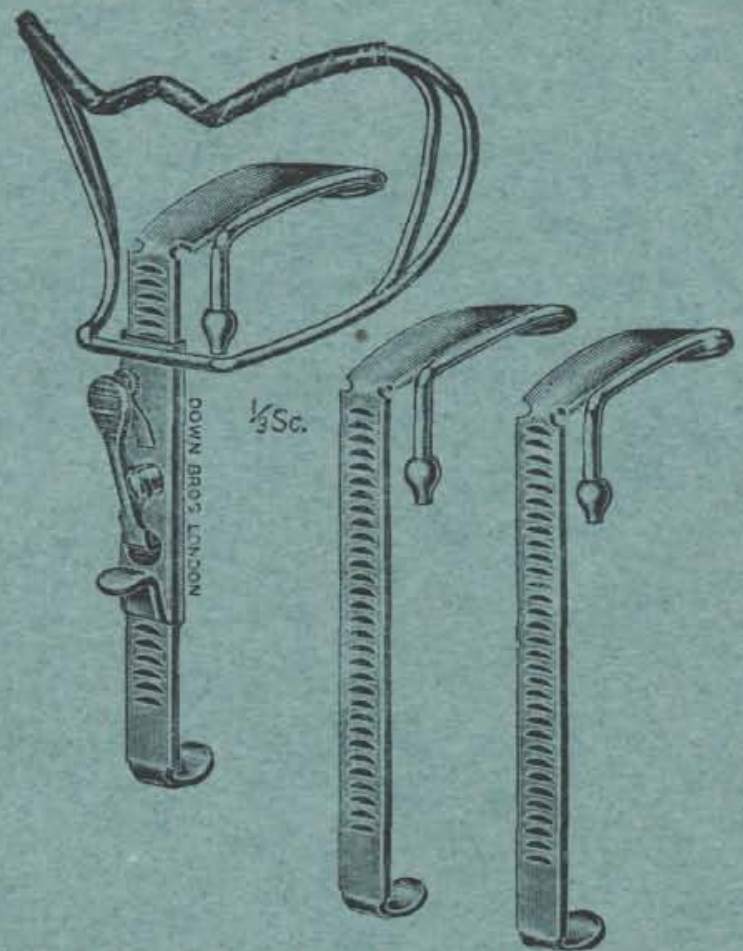

Gag Frame supplied with set of 5 Tongue Plates

\section{ADVANTAGES:}

1. Elimination of dental trauma.

2. Improved accessibility to both sides.

3. Resilience to absorb the shock of any forceful manipulations.

4. One standard size of frame necessary for all ages (but tongue plates for different ages are necessary).

\section{DOWN BROS. AND MAYER \& PHELPS LTD CHURCH PATH, MITCHAM, SURREY}

Telephone: MITCHAM 6291

Showrooms and Branches:

32 New Cavendish Street

London, W.1
410 Dundas Street West

Toronto, 2B Canada 